\title{
Vol. 21, 2008
}
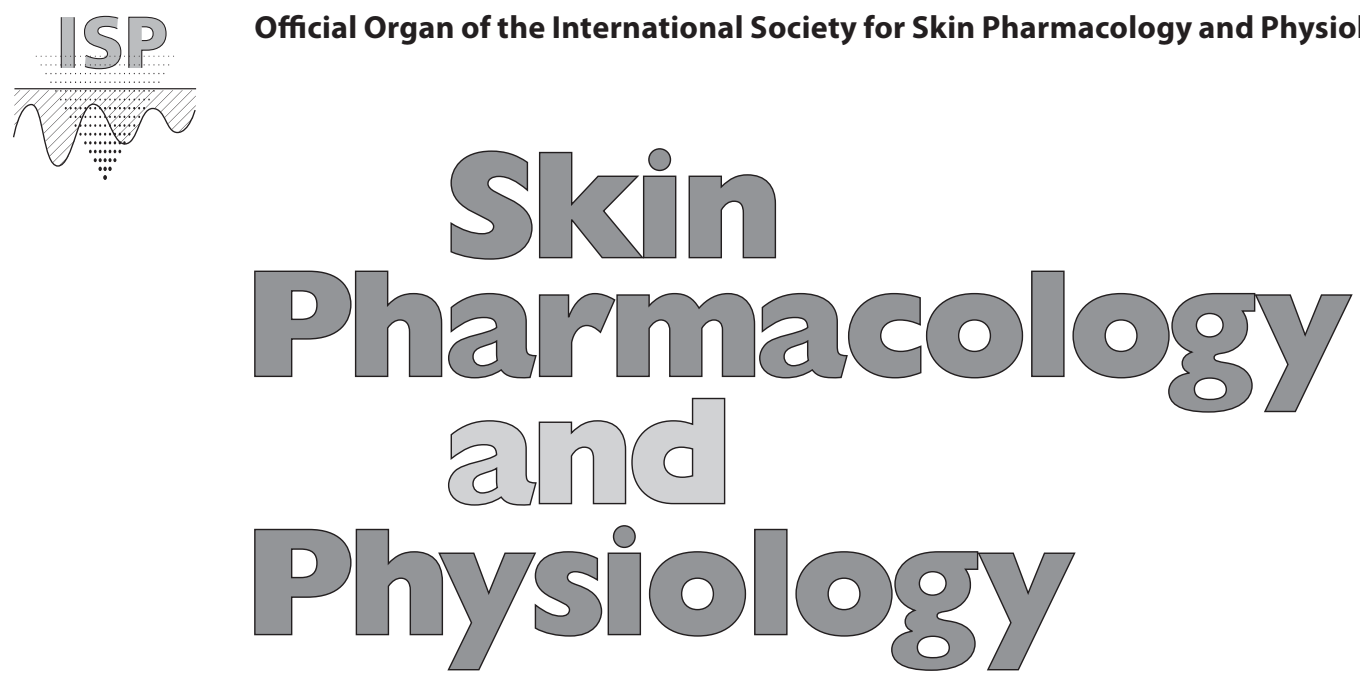

Journal of Pharmacological and Biophysical Research

Founded in 1988 by H. Schaefer as 'Skin Pharmacology'

Edited 1993-2002 by H.F. Merk

1998-2003 'Skin Pharmacology and Applied Skin Physiology'

Incorporating 'Bioengineering and the Skin'

\section{Editor}

\section{Editorial Board}

\section{J. Lademann, Berlin}

\section{Honorary Editors}

H.F. Merk, Aachen

\section{Associate Editors}

P. Elias, San Francisco, Calif.

J.W. Fluhr, Berlin

H.I. Maibach, San Francisco, Calif.

H. Mukhtar, Madison, Wisc.

G. Nohynek, Clichy

M. Roberts, Brisbane

S. Shapiro, Skillman, N.J.

C. Surber, Egerkingen

H. Tagami, Sendai

P. van de Kerkhof, Nijmegen
N. Ahmad, Madison, Wisc.

P. Altmeyer, Bochum

C. Antoniou, Athens

H. Bachelez, Paris

J.M. Baron, Aachen

E. Benfeldt, Copenhagen

E. Berardesca, Rome

D.R. Bickers, New York, N.Y.

J.E. Birnbaum, East Hanover, N.J.

K. de Paepe, Brussels

P. Elsner, Jena

A. Farkas, Szeged

A. Giannetti, Modena

M.W. Greaves, Kuala Lumpur

R. Guy, Bath
J. Hadgraft, Chatham Maritime

B.M. Henz, Berlin

E.M. Jackson, Sumner, Wash.

Y. Kawakubo, Saitama

H.-C. Korting, Munich

J. Krutmann, Düsseldorf

R. Neubert, Halle

D. Roop, Houston, Tex.

T. Ruzicka, Munich

M. Schäfer-Korting, Berlin

S. Seidenari, Modena

B. Shroot, San Antonio, Tex.

J. Wohlrab, Halle

S. Yamamoto, Hiroshima 


\section{Skin \\ Pharmacology खल \\ Physiology}

No. 1

1 Editorial

2 Acknowledgements to Reviewers

Review

3 Dermal Peptide Delivery Using Colloidal Carrier Systems Goebel, A.; Neubert, R.H.H. (Halle/Saale)

Original Papers

10 Subungual Penetration of Dibutyl Phthalate in Human Fingernails Jackson, E.M. (Sumner, Wash.)

15 Molecular Basis for the Regenerative Properties of a Secretion of the Mollusk Cryptomphalus aspersa

Brieva, A. (Madrid); Philips, N. (Teaneck, N.J.); Tejedor, R.; Guerrero, A.; Pivel, J.P.; Alonso-Lebrero, J.L. (Madrid); Gonzalez, S. (New York, N.Y.)

23 Transdermal Penetration of UV Filters

Klinubol, P.; Asawanonda, P.; Wanichwecharungruang, S.P. (Bangkok)

30 In vivo and in vitro Skin Permeation of Butyl

Methoxydibenzoylmethane from Lipospheres

Iannuccelli, V.; Coppi, G.; Sergi, S. (Modena); Mezzena, M.; Scalia, S. (Ferrara)

39 Placebo-Controlled, Double-Blind, Randomized, Prospective Study of a Glycerol-Based Emollient on Eczematous Skin in Atopic Dermatitis: Biophysical and Clinical Evaluation Breternitz, M.; Kowatzki, D. (Jena); Langenauer, M. (Egerkingen); Elsner, P.; Fluhr, J.W. (Jena)

50 The Influence of a Non-Occlusive Bi-Layer Composite Membrane on Skin Barrier Properties. A Non-Invasive Evaluation with a Right-Left Intra-Individual Pre/Post Comparison Study

Brazzelli, V. (Pavia); Berardesca, E. (Rome); Rona, C.; Borroni, G. (Pavia)

Short Communication

46 Topical Delivery of Retinyl Ascorbate. 3. Influence of Follicle Sealing and Skin Stretching

Abdulmajed, K.; Heard, C.M. (Cardiff)
No. 2

Editorial

57 4th Meeting of the ISP and This Issue at a Glance Lademann, J.; Fluhr, J. (Berlin)

Reviews

58 Properties of Ceramides and Their Impact on the Stratum Corneum Structure: A Review. Part 2: Stratum Corneum Lipid Model Systems

Kessner, D.; Ruettinger, A. (Halle-Saale); Kiselev, M.A. (Dubna); Wartewig, S.; Neubert, R.H.H. (Halle-Saale)

75 The Role of Emollients in the Management of Diseases with Chronic Dry Skin

Proksch, E. (Kiel)

Original Papers

81 Influence of Human Skin Specimens Consisting of Different Skin Layers on the Result of in vitro Permeation Experiments Henning, A.; Neumann, D. (Saarbrücken); Kostka, K.-H. (Lebach); Lehr, C.-M.; Schaefer, U.F. (Saarbrücken)

89 Improvement of the Experimental Setup for Skin Absorption Screening Studies with Reconstructed Skin EPISKIN ${ }^{\circledR}$

Grégoire, S.; Patouillet, C.; Noé, C.; Fossa, I.; Benech Kieffer, F.; Ribaud, C. (Aulnay-sous-Bois)

98 Inhibition of Dermal MRSA Colonization by Microalgal Micro- and Nanoparticles

Lukowski, G.; Lindequist, U.; Mundt, S.; Kramer, A.; Jülich, W.-D. (Greifswald)

106 Investigation of the Anti-Inflammatory Potential of Aloe vera Gel (97.5\%) in the Ultraviolet Erythema Test

Reuter, J.; Jocher, A.; Stump, J. (Freiburg); Grossjohann, B.; Franke, G. (Insel-Riems); Schempp, C.M. (Freiburg)

111 Epidermal Ceramidase Activity Regulates Epidermal Desquamation via Stratum Corneum Acidification Houben, E.; Hachem, J.P.; De Paepe, K.; Rogiers, V. (Brussels)

\section{KARGER}

Fax +41613061234 E-Mail karger@karger.ch www.karger.com

\section{(c) 2008 S. Karger AG, Basel}

Access to full text and tables of contents, including tentative ones for forthcoming issues: www.karger.com/spp_issues 


\section{No. 3}

International Society of Skin Pharmacology,

Meeting Highlights.

Washington, D.C., August 11-13, 2007

Editors: Jürgen Lademann (Berlin); Joachim W. Fluhr (Berlin);

Reinhard H.H. Neubert (Halle/Saale)

123 Editorial

Fluhr, J.W.; Lademann, J. (Berlin)

Reviews

124 Skin Irritation and Sensitization: Mechanisms and New Approaches for Risk Assessment. 1. Skin Irritation

Fluhr, J.W. (Berlin); Darlenski, R. (Sofia); Angelova-Fischer, I. (Lübeck); Tsankov, N. (Sofia); Basketter, D. (Sharnbrook)

136 Nanotechnology, Cosmetics and the Skin: Is There a Health Risk?

Nohynek, G.J.; Dufour, E.K. (Asnières); Roberts, M.S. (Brisbane, Qld.)

150 Hair Follicles - An Efficient Storage and Penetration Pathway for Topically Applied Substances. Summary of Recent Results Obtained at the Center of Experimental and Applied Cutaneous Physiology, Charité - Universitätsmedizin Berlin, Germany Lademann, J.; Knorr, F.; Richter, H.; Blume-Peytavi, U.; Vogt, A. (Berlin); Antoniou, C. (Athens); Sterry, W.; Patzelt, A. (Berlin)

156 Optical Methods for Measurements of Skin Penetration Gotter, B. (Halle/Saale); Faubel, W. (Karlsruhe); Neubert, R.H.H. (Halle/Saale)

Original Papers

166 Assessment of Quantum Dot Penetration into Intact, Tape-Stripped, Abraded and Flexed Rat Skin Zhang, L.W.; Monteiro-Riviere, N.A. (Raleigh, N.C.)

181 Activity of Different Desoximetasone Preparations Compared to Other Topical Corticosteroids in the Vasoconstriction Assay Borelli, C. (München); Gassmueller, J.; Fluhr, J.W. (Hamburg); Nietsch, K.H.; Schinzel, S. (Berlin); Korting, H.C. (München)

188 Author Index and Subject Index

No. 4

Obituary

189 Steven Karger (1959-2008)

Karger, T. (Basel)

Editorial

190 This Issue at a Glance

Fluhr, J.; Lademann, J. (Berlin)

Reviews

191 Skin Irritation and Sensitization: Mechanisms and New Approaches for Risk Assessment. 2. Skin Sensitization Basketter, D. (Sharnbrook); Darlenski, R. (Sofia); Fluhr, J.W. (Berlin)

203 Fungicidal Activity Plus Reservoir Effect Allow Short Treatment Courses with Terbinafine in Tinea pedis Schäfer-Korting, M. (Berlin); Schoellmann, C.; Korting, H.C. (Munich)

Original Papers

211 Claudin 2 mRNA and Protein Are Present in Human Keratinocytes and May Be Regulated by All-trans-Retinoic Acid

Telgenhoff, D.; Ramsay, S.; Hilz, S.; Slusarewicz, P.; Shroot, B. (Fort Worth, Tex.)
218 Characterization of Rabbit Ear Skin as a Skin Model for in vitro Transdermal Permeation Experiments: Histology, Lipid Composition and Permeability

Nicoli, S.; Padula, C.; Aversa, V.; Vietti, B. (Parma); Wertz, P.W. (Iowa City, Iowa); Millet, A.; Falson, F. (Lyon); Govoni, P.; Santi, P. (Parma)

227 Antiproliferative Effect of Vitamin A and D Analogues on Adult Human Keratinocytes in vitro

Popadic, S.; Ramic, Z.; Medenica, L.; Mostarica Stojkovic, M.; Trajković, V.; Popadic, D. (Belgrade)

235 Permeation and Metabolism of a Novel Ascorbic Acid Derivative, Disodium Isostearyl 2-O-L-Ascorbyl Phosphate, in Human Living Skin Equivalent Models

Shibayama, H. (Shimotsuke/Osaka); Hisama, M.; Matsuda, S. (Osaka); Ohtsuki, M. (Shimotsuke)

No. 5

Editorial

245 This Issue at a Glance: Skin Reactions of Astronauts in Space and Microstructures of Topically Applied Formulations Lademann, J.; Fluhr, J. (Berlin)

Review

246 Application of Microemulsions in Dermal and Transdermal Drug Delivery

Santos, P.; Watkinson, A.C.; Hadgraft, J.; Lane, M.E. (London/

West Melbourne, Vic.)

Original Papers

260 Molecular Characterization of Inflammation and Staphylococcus aureus Colonization of Involved Skin of Atopic Dermatitis Patients. A Non-Invasive Approach

Casas, C. (Toulouse); Ginisty, H. (Labège); Alvarez-Georges, S.; Viodé, C.; Lejeune, O.; Rouvrais, C.; Schmitt, A.M.; Redoulès, D. (Toulouse)

269 Protein Carbonyls Damage the Water-Holding Capacity of the Stratum Corneum

Iwai, I.; Hirao, T. (Yokohama)

274 Influence of Microparticles on the Homogeneity of Distribution of Topically Applied Substances

Lademann, J.; Richter, H. (Berlin); Golz, K.; Zastrow, L. (Monaco); Sterry, W.; Patzelt, A. (Berlin)

283 Change in Skin Physiological Parameters in Space - Report on and Results of the First Study on Man

Tronnier, H.; Wiebusch, M.; Heinrich, U. (Witten)

No. 6

Editorial

293 Penetration Properties and Safety Aspects of Topically Applied Products

Fluhr, J.; Lademann, J. (Berlin)

Review

294 Role of Physical Chemical Properties in Drug Relay into Skin Compartments

Fortenbach, C.R. (San Francisco, Calif.); Modjtahedi, B.S.

(San Francisco, Calif./Davis, Calif.); Maibach, H.I. (San Francisco, Calif.) 
Original Papers

300 Safety of Topical Methimazole for the Treatment of Melasma. Transdermal Absorption, the Effect on Thyroid Function and Cutaneous Adverse Effects

Kasraee, B. (Geneva/Shiraz); Safaee Ardekani, G.H.; Parhizgar, A. (Jahrom); Handjani, F.; Omrani, G.R.; Samani, M. (Shiraz); Nikbakhsh, M.; Tanideh, N.; Eshraghian, A. (Jahrom); Sorg, O.; Saurat, J.H. (Geneva)

306 Skin Tolerance of a New Bath Oil Containing St. John's Wort Extract

Reuter, J.; Huyke, C.; Scheuvens, H. (Freiburg); Ploch, M. (Cologne); Neumann, K. (Berlin); Jakob, T.; Schempp, C.M. (Freiburg)

312 Optical Coherent Tomography for in vivo Determination of Changes in Hair Cross Section and Diameter during Treatment with Glucocorticosteroids - A Simple Method to Screen for Doping Substances?

Lademann, J. (Berlin); Shevtsova, J. (Moscow); Patzelt, A.; Richter, H. (Berlin); Gladkowa, N.D.; Gelikonov, V.M. (Nizhniy Novgorod); Gonchukov, S.A. (Moscow); Sterry, W. (Berlin);

Sergeev, A.M. (Nizhniy Novgorod); Blume-Peytavi, U. (Berlin)
318 Skin Permeation and Distribution of Two Sunscreens: A Comparison between Reconstituted Human Skin and Hairless Rat Skin

Monti, D.; Brini, I.; Tampucci, S.; Chetoni, P.; Burgalassi, S. (Pisa); Paganuzzi, D.; Ghirardini, A. (Colorno)

326 Effect of Penetration Modifiers on the Dermal and Transdermal Delivery of Drugs and Cosmetic Active Ingredients

Otto, A. (Potchefstroom); Wiechers, J.W. (Gouda/London); Kelly, C.L.

(Wilton); Hadgraft, J. (Potchefstroom/London); du Plessis, J. (Potchefstroom)

335 Author Index Vol. 21, 2008

336 Subject Index Vol. 21, 2008

\section{S. Karger}

Medical and Scientific Publishers

Basel • Freiburg • Paris • London •

New York $\cdot$ Bangalore $\cdot$ Bangkok •

Shanghai $\cdot$ Singapore $\cdot$ Tokyo $\cdot$ Sydney
Disclaimer

The statements, opinions and data contained in this publication are solely those of the individual authors and contributors and not of the publisher and the editor(s). The appearance of advertisements in the journal is not a warranty, endorsement or approval of the products or services advertised or of thei effectiveness, quality or safety. The publisher and the editor(s) disclaim responsibility for any injury to persons or property resulting from any ideas, methods, instructions or products referred to in the content or advertisements.

Drug Dosage

The authors and the publisher have exerted every effort to ensure that drug selection and dosage set forth in this text are in accord with current recommendations and practice at the time of publication. However, in view of ongoing research, changes in government regulations, and the constant flow of information relating to drug therapy and drug reactions, the reader is urged to check the package insert for each drug for any change in indications and dosage and for added warnings and precautions. This is particularly important when the recommended agent is a new and/or infrequently employed drug.
All rights reserved.

No part of this publication may be translated into other languages, reproduced or utilized in any form or by any means, electronic or mechanical, including photocopying, recording, microcopying, or by any information storage and retrieval system, without permission in writing from the publisher or, in the case of photocopying, direct payment of a specified fee to the Copyright Clearance Center (see 'General Information')

(c) Copyright 2008 by S. Karger AG,

P.O. Box, CH-4009 Basel (Switzerland) Printed in Switzerland

on acid-free and non-aging paper (ISO 9706) by

Reinhardt Druck, Basel 